\title{
The Trade Unions Performance in Tanzania: The Perceptions of School Teachers Union in Singida Municipality
}

\author{
Ausi Nchimbi \\ Tanzania Public Service College (TPSC), Singida, Tanzania \\ Email:nchimbiausi@gmail.com
}

How to cite this paper: Nchimbi, A. (2018) The Trade Unions Performance in Tanzania: The Perceptions of School Teachers Union in Singida Municipality. Open Journal of Social Sciences, 6, 242-254. https://doi.org/10.4236/jss.2018.64021

Received: March 21, 2018

Accepted: April 27, 2018

Published: April 30, 2018

Copyright $\odot 2018$ by author and Scientific Research Publishing Inc. This work is licensed under the Creative Commons Attribution International License (CC BY 4.0).

http://creativecommons.org/licenses/by/4.0/

\section{(c) (i) Open Access}

\begin{abstract}
This study explored the perception of teachers as members of trade unions on the effectiveness of their trade union; using Tanzania Teacher's Union, as a case study. The study adopted a case study strategy where ten schools were involved in the study. Both qualitative and quantitative methods and approaches were used in data collection and analysis. A total sample of 209 respondents was involved in the study. Documentary review was also adopted, where various documents related to the study were critically reviewed. The results demonstrated that members of TTU have positive perception on the effectiveness of TTU as a workers' representation and do represents its members. However respondents were skeptical on the issue of communication and keeping the members up to date on what is real going on within the union.
\end{abstract}

\section{Keywords}

Trade Unions, Effectiveness, Organizations, Performance

\section{Introduction}

Trade unions can be described as the organized groupings of wage and salary earners with the purpose bringing to bear the economic, social, political and political interests of their members in labor relations and political system (Schillinger, 2005) [1]. The main purpose of trade unions is to maintain or improving the employment conditions of their members. Workers unions provides forum through which collective bargaining is used primary to secure worker's economic rights (Babeiya, 2011) [2]. As new type of organizations trade unions emerged during industrialization in Europe in the second half of $19^{\text {th }}$, century. They later developed into more comprehensive organizations of the rapidly growing indus- 
tries (Schillinger, 2005) [1].

In Africa the organizations of wage and salary earners started after the World War Two when some of the colonial administrators put in place the legal prerequisites for the creation of indigenous labor organizations. Due to the absence of strong industrial base in Africa trade unions were mainly emerged in the public service and the public transport sector, mostly for teachers, railway and port workers. Labor organizations were also formed in the mining sector and to a lesser extent, in the plantation economy of east Africa (Thomas, 1999) [3].

Historically trade unionism in Africa were regarded as an important and driving force for the anti-colonial liberalization struggle, before they were transformed in to transmission belts of ruling parties. Most of the present literature on trade unions in Africa argues for reducing efficiency of trade unions (Schillinger, 2005) [1]. In Tanzania like other African Countries labor Unions played a vital role in the economic, political and social evolution of the country since 1940's (Mukandala, 1999) [4]. Apart from representing workers on issues of common interests, the labor movements also acted as a freedom fighting movements against British colonial rule. However after the independence trade unions experienced a weak influence and power to effectively represent its members (Kamugisha \& Tefurukwa, 2015) [5].

On the other hand there is extensive literature on the effectiveness of trade unions in Africa there is a little empirical research on what makes unions effective in the eyes of employees (members). Employees are rational actors in their decisions to join trade unions. The desire of nonmembers for membership and member's satisfaction with representation by their unions are higher where the union is perceived as an effective organization capable of delivering better terms and conditions for employees (Bryson, 2003) [6]. If the union is perceived as effective employees are more likely to think they have something tangible to gain from membership, either in terms of better wages, better non-pecuniary terms of employment or better assurance against arbitrary employer actions. Therefore in discussing the effectiveness of trade unions in Tanzania it is critical to focus on the perception of its members. It is from the above backdrop that this paper conceived to understand the effectiveness of trade unionism in Tanzania basing on the perception of teachers from Singida Municipality.

\section{Objectives of the Study}

The general objective of this study was to explore the perception of Tanzania teachers concerning the performance of their trade unions. More specifically the study attempted to:

a) To assess the effectiveness of the trade union in communicating and sharing information with its members;

b) To determine the responsiveness of the trade union towards members' problems and complaints;

c) To determine whether the employer; (Government) is in favor of the trade union (TTU); 
d) To evaluate the performance of the union to fulfill its objective as a worker's representation

\section{Literature Review}

\subsection{The Role of Trade Unions: General Perspective}

In order to further enlighten this study, it is important to include section on the role of trade unions since it is difficult to measure the effectiveness of trade unions if the main functions of unions are not clearly identified. According to Ghosh et al. (2009) [7] "Trade unions are legitmate system for organizing and promotion of worker's rights and dealing with workers' grievances". According to Babeiya (2011) [2] trade unions have the responsibility of protecting the worker's economic rights as their main responsibility. The exclusive purpose of a trade union is to protect the professional interests of its members. Babeiya (2011) [2]

According to Ghosh et al (2009) [7], Babeya, 2011 [2], and International Labour Organization (2013) [8] the following are the primary objectives of Trade unions; to improve working and living conditions and to represent worker's interests in various for a (freeman \& Medoff 1984 in Ghosh and et al 2009) [7], to offer responsive cooperation in improving levels of production and productivity, discipline and high standard of quality, to secure fair wages for workers, to enlarge opportunities for promotion and training, to promote identity of worker's interests with their industries, to cooperate in and facilitate technological advancement by broadening worker understands of underlying issues, and to influence the state by making it more concerned about worker's rights (Babeiya, 2011) [2]. Apart from primary objectives of which trade unions play in the world of work, there are also other additional roles performed by the trade unions such as communication, welfare, education and research undertakings (Monappa, 2000, in Ghosh et al., 2009) [7]. Through communication, unions are able to propagate and clarify information about their activities and policy. Through welfare activities, the labor unions are able to help their members in such matters as housing for example in quest to improve the member's quality of life.

\subsection{Conceptualization of Organization Effectiveness}

Organizational effectiveness has been defined in a countless of forms, and there seems to be no consensus as to what constitutes a more universally agreeable definition (Gibson et al. 1991) [9]. However, organizational effectiveness according to Zammuto [10] can be defined as the extent to which an organization is able to realize its objective goals in line with its mandate. Thus what is mean by effectiveness is the accomplishment of recognized objectives of cooperative effort. The degree of accomplishment indicates the degree of effectiveness" (Gibson et al., 9991) [9]. In organizational and management studies, this is named as the goal approach model and its construct is based on proposition that "an organization is effective to the extent that it accomplishes its stated goals" (Cameron, 
1986) [11]. Thus, according to Cameron, the goal approach model thrives in situations where the intended goals are unambiguous, universally agreeable, to be attained within a specified period and can be measured. Despite that other organizational effectiveness models exist, like the systems model, internal process model among others, the goal-oriented model seems to be more relevant with this study. Also there is little research on what makes unions effective in the eyes of the employees. According to Bryson (2003) [6], unions need to identify practical methods like improving the perception of employees regarding union effectiveness as one way to recruit and retain membership. Therefore this study aims to explore the effectiveness of trade unions in Tanzania basing on the perspective of the employees/members.

\subsection{Trade Unions in Tanzania: Background and Experience}

The advent of trade unionism in Tanzania can be dated back to colonial days following the introduction of permanent wage labours. The first organizational initiative to form a trade union, according to existing records in 1927 when African motor Drivers and Mechanics in Moshi formed the union and even attempted to stage a strike for the higher wages (Shivji, 1986) [12]. The union was silenced by the colonial government and was not heard any more. In 1930's The Tanganyika African Government Servants Association was formed however it didn't pose any threat to government (Mukandala, 1999) [4]. With the advent of nationalist struggles for self-government and independence led by TANU the formation of trade unions was reinforced by the end of 1956 there were twenty three unions with about 13,000 members. In 1955 Tanganyika Federation of Labour (TFL) was formed this was the significant achievement in the history of trade union in Tanzania (Mukandala, 1999) [4]. During Independence Struggle the nationalist movement led by TANU and the union movement led by TFL joined hands to fight a common enemy imperialist domination through colonialism however after independence the relationship between TANU and trade unions went unfriendly.

After independence the Tanzania Government led by TANU had actively legislated in order to manage labour organizations. Reading through Acts made after independence one notes that the freedom of Trade Unions obtained through hard struggle had been curtailed. There was established a sole trade union by State legislation, and there was ouster of jurisdiction of ordinary courts of laws with regard to laws affecting disciplinary code and settlement of disputes in certain areas. Kamugisha \& Tefurukwa (2015) [5] noted that in 1964 the government enacted Act No. 818 to undermine the autonomy of trade unions. Its repercussion was that, NUTA was affiliated to TANU, membership was compulsory; the president had the power to dissolve or establish trade unions, and some employees earning high salaries were denied membership. Bana (2011) [13] viewed all these as the breach of the ILO requirements that forbidden trade unions to depend on political parties. The government introduced the new trade 
unions Act No. 24 of 1979 and the Jumuiya ya Wafanyakazi Tanzania (JUWATA) was formed. The ruling part entirely dominated the new trade union. JUWATA was like NUTA its operation and coverage, although it incorporated Tanzania Zanzibar. JUWATA resulted to the formation of the Organization of Trade Unions (OTTU) which imitated characteristics from JUWATA. All these accounted for the ineffective of the trade Unions to effectively represent the demand of its members. As Babeya (2011) [2] observed that due to all these; trade unions were not autonomous as they were the victims of strictly control from the state which was the main employer.

With the introduction of multiparty democracy the labour movement scenario in Tanzania had completely changed. Trade unions were now legally made autonomous from 1998 when the OTTU act was repealed by the trade union Act No. 10 of 1998 [14] in which the Trade Union Congress of Tanzania (TUCTA) as a federation was established in 2001 legally replacing OTTU (Bana \& Mukandala, 2006) [15]. Act No. 10 of 1998 resulted to the formation of many trade unions in Tanzania the thing which resulted to the fragmentation. Finally the power and the role of Trade Unions declined. This has rendered it partially impotent to be able to fight effectively for workers' interests.

The prescriptions of the international Monetary Fund (IMF), the World Bank and the advent of New Public management resulted in the move to make the Government of Tanzania small to cut off unnecessary expenditures. The government as the major employer retrenched its employees. This resulted in substantial loss jobs to many Tanzanians in the formal economy. The labor movement in Tanzania experienced a sharp split which left it severely weakened. The general situation of the labor movement in Tanzania since independence up to the present is in a dismal state mostly due to its weakened state and hence lack of ability to effectively champion the cause of its members. Further Kamugisha \& Tefurukwa (2015) [5] observes that government interference in the affairs of the labor movement has eroded its vibrancy.

\subsection{Trade Unions in Tanzania: Legal and Regulatory Framework}

The constitution of the United Republic of Tanzania of 1977 forms the basis upon which the fundamental rights of association to belong to any organization are founded upon. Article 20, sub-article 1) of the Constitution of Tanzania of 1977 [16] States satates that, Every person has a freedom, to freely and Peacefully assemble, associate and cooperate with other persons, and for that purpose, express views publicly and to form and join with associations or organizations formed for purposes of preserving or furthering his beliefs or interests or any other interests. By linking with the Constitution of United Republic of Tanzania trade unions in Tanzania are formed in accordance with the provisions of the employment and Labor Relations Act No 6 of 2004 [17]. This Act provides the legislative framework regarding the formation, registration and general operations and management of trade unions. It also sets the road map for strike and lockout action, collective bargaining, and employment dispute resolution. The 
act defines trade unions as and also the tripartite consultative mechanism.

\section{Methodology}

The study was aimed to explore the perception of workers on the performance of trade unions in Tanzania. Therefore the design adopted for the study was a case study strategy where ten schools were involved. Both Quantitative and qualitative primary empirical data were collected through survey questionnaires distributed to members of Tanzania teachers Union (TTU) and interviews. The study investigated participant's perceptions of trade union effectiveness in Tanzania by using an attitude scale to measure participant's position on questionnaire statements.

\subsection{Sample Population}

The target population was members of Tanzania Teacher's Trade Union (TTU) which is the only Trade Union with large number of members in Tanzania and its members are primary and secondary school teachers. The data were collected from secondary and primary schools located in Singida Municipality. The totals of ten schools were selected comprised of 5 primary schools and 5 secondary schools. The respondents were teachers who are members of TTU and therefore the total sample size was 209 teachers.

\subsection{The Instrument Used}

The survey instrument used to collect data was questionnaire. The questionnaire was divided in to three parts. Part 1 comprised questions related to the demographic characteristics of the respondents. Part two comprised questions related to overall perception of respondents on unions ability to communicate with its members and union's responsiveness on the member's problems and part 3 comprised with the questions related to overall perception of respondents on the performance of the union. The instrument was first pilot tested with two schools including one primary school and the second was the secondary school. A total number of ten teachers were selected to fill the questionnaire. This was done to ensure the validity of the research instrument. Their suggestions were incorporated before the distribution of the final questionnaire to the selected sample of the study.

\section{Findings and Discussion}

\subsection{Demographic Background of the Respondents}

The demographic characteristics of the respondents of the study, as shown in Table 1, revealed that majority (123 (58.9\%) of respondents are females while the remaining (86 (41.1\%) are males. Furthermore, most of respondents (42.6\%) were between the age group $31-45$. Followed by those within the age group of 18 - 30 years (28\%) Respondents within the age group 55 years and above comprised a small number of $7.7 \%$ making them the least represented of all the age groups profiled in the study. 
Table 1. Demographic data of the respondents.

\begin{tabular}{|c|c|c|}
\hline Demographics & Number of Respondents (N) & Percentage (\%) \\
\hline Total sample & 209 & 100 \\
\hline \multicolumn{3}{|c|}{$\operatorname{sex}$} \\
\hline Male & 86 & 41.1 \\
\hline Female & 123 & 58.9 \\
\hline Total & 209 & 100 \\
\hline \multicolumn{3}{|c|}{ Age } \\
\hline $18-30$ Years & 60 & 28.7 \\
\hline 31 - 45 Years & 89 & 42.6 \\
\hline $46-55$ Years & 44 & 21.1 \\
\hline 55 Years and Above & 16 & 7.7 \\
\hline Total & 209 & 100 \\
\hline \multicolumn{3}{|c|}{ Education Level } \\
\hline Certificate/Diploma & 116 & 55.5 \\
\hline University Degree & 93 & 44.5 \\
\hline Total & 209 & 100 \\
\hline \multicolumn{3}{|c|}{ Length of Union Membership } \\
\hline Less than 1 year & 18 & 8.6 \\
\hline $1-5$ Years & 68 & 32.5 \\
\hline 5 - 10 Years & 48 & 2 \\
\hline 10 - 20 Years & 33 & 15.8 \\
\hline More than 20 Years & 42 & 20.8 \\
\hline Total & 209 & 100 \\
\hline
\end{tabular}

Source: Field data (2017).

In order to cover the cross-reference the above observed trend and to ensure that the data were unbiased, respondent's years of their membership of the trade union were also examined. The results shows that respondents who have been members of the union between 1 - 5 years comprised majority of 68 equals to $32.5 \% /$ those who have been members for 5 - 10 years were second with $23 \%$ and those with more than twenty years of membership were third with $20.8 \%$. Furthermore those with less than one year of membership occupied the least representation of this study. Table 1 shows further statistical analysis of the demographics of respondents. This is interesting because the study comprises with experienced teachers.

\subsection{The Effectiveness of the Trade Union in Communicating and Sharing Information with Its Members}

The effectiveness of the trade union in communicating and sharing information 
with its members was also examined. This aimed at finding out how effective is the trade unions in sharing information with its members. The results as shown in Table 2 reveal that, majority of respondents $49.3 \%$ Disagreed that the union shares information with its members. This shows that the members of the union have no access to information of their trade union. The results also shows that there is no consensus among the members of the union on how often the union shares its information as shown in Table 3 below. This indicates that the union members are not so sure on how often the union shares its information with its members. This may be caused by inconsistency of TTU in sharing information to its members. It is important to note that the members of a trade union have the right to know what their organization does, how the various conflicts and situations are handled and about the decisions of board members and other important leaders of the union. Members need the best possible information about the policy and what is real happening within and outside the union.

Respondents were also asked to provide their opinion whether the information provided by TTU is useful or not. The results as shown in Table 3 indicate that majority of respondents $53.6 \%$ agreed that the information shared by TTU is useful. $23.4 \%$ of the respondents disagree that the information provided by TTU is useful $17.2 \%$ of respondents do not agree that the information provided by TTU is useful $4.3 \%$ of respondents strongly disagree that the information provided by TTU is useful while the minority $1.4 \%$ strongly agree that the information shared by TTU to its members is useful. The results above depict a positive perception of TTU members towards the information shared to its members.

\subsection{The Responsiveness of the Trade Union towards Members' Problems and Complaints}

The study also interested to know the responsiveness of TTU towards members problems and complains. Table 4 depicts the perception of trade union members regarding its effectiveness towards member's problems and complains. The results indicated that $33.5 \%$ of the respondents agreed that the union is responsive towards member's problems and complains. $21.5 \%$ of the respondents

Table 2. The union communicates and shares information about its activities.

\begin{tabular}{cccccc}
\hline & & Frequency & Percent & Valid Percent & Cumulative Percent \\
\hline \multirow{4}{*}{ Valid } & Agree & 55 & 26.3 & 26.7 & 26.7 \\
& Don't know & 22 & 10.5 & 10.7 & 37.4 \\
& Disagree & 103 & 49.3 & 50.0 & 87.4 \\
& Strongly disagree & 26 & 12.4 & 12.6 & 100.0 \\
\multirow{4}{*}{ Missing } & Total & 206 & 98.6 & 100.0 & \\
& 12 & 3 & 1.4 & & \\
& Total & 209 & 100.0 & & \\
\hline
\end{tabular}

Source: Field data (2017). 
Table 3. How often the TTU does shares its information?

\begin{tabular}{cccccc}
\hline & & Frequency & Percent & Valid Percent & Cumulative Percent \\
\hline \multirow{4}{*}{ Valid } & monthly & 17 & 8.1 & 9.6 & 9.6 \\
& six months & 42 & 20.1 & 23.7 & 33.3 \\
& Every year & 45 & 21.5 & 25.4 & 58.8 \\
& I don't know & 73 & 34.9 & 41.2 & 100.0 \\
& Total & 177 & 84.7 & 100.0 & \\
\multirow{3}{*}{ Missing } & 13 & 32 & 15.3 & & \\
& Total & 209 & 100.0 & & \\
\hline
\end{tabular}

Source: Field data (2017).

Table 4. The union takes up and responds to member's problems and complains seriously.

\begin{tabular}{cccccc}
\hline & Frequency & Percent & Valid Percent & $\begin{array}{c}\text { Cumulative } \\
\text { Percent }\end{array}$ \\
\hline \multirow{4}{*}{ Valid } & Strongly agree & 10 & 4.8 & 4.8 & 4.8 \\
& Agree & 70 & 33.5 & 33.5 & 38.3 \\
& Don't know & 43 & 20.6 & 20.6 & 58.9 \\
& Disagree & 45 & 21.5 & 21.5 & 80.4 \\
& Strongly disagree & 41 & 19.6 & 19.6 & 100.0 \\
& Total & 209 & 100.0 & 100.0 &
\end{tabular}

Source: Field data (2017).

disagree that the union is not responsive towards member's problems and complains. 20.6\% of respondents don't understand whether the union was responsive to member's problems and complaints. $19.6 \%$ of respondents strongly disagree that the union is responsive towards member's problems and complains. While $4.5 \%$ of respondents strongly agreed that the union was responsive towards member's problems and complains. On the other hand, 33.5\% of respondents agreed that the union is responsive towards member's problems and complains this percent is not strongly enough to conclude that the union is responsive. Most workers join trade unions with the expectation of being protected from exploitation and believing that trade unions are the voice of workers, and that their problems and complains can be solved through them. Therefore their perception on how trade union is effective on responding their workplace problems and complains is significant important. As put forward by Mpangala (2006) [18] that, if Tanzania trade unions want to satisfy its members must set their minds to think for their members first and not their individual interests.

\subsection{To Determine Whether the Employer; Government Is in Favor of the Trade Union (TTU)}

As it shown in Table 5, the majority of respondents $41.1 \%$ agreed that the government respects and takes the union and its activities seriously. $29.2 \%$ stated that they do not know whether the government respects and takes the union and its activities seriously. $25.4 \%$ of respondents disagree that the Government 
Table 5. The Government respects and takes the union and its activities seriously.

\begin{tabular}{cccccc}
\hline & & Frequency & Percent & Valid Percent & Cumulative Percent \\
\hline \multirow{4}{*}{ Valid } & Strongly agree & 5 & 2.4 & 2.4 & 2.4 \\
& Agree & 86 & 41.1 & 41.1 & 43.5 \\
& Don't know & 61 & 29.2 & 29.2 & 72.7 \\
& Disagree & 53 & 25.4 & 25.4 & 98.1 \\
& Strongly disagree & 4 & 1.9 & 1.9 & 100.0 \\
& Total & 209 & 100.0 & 100.0 & \\
\hline
\end{tabular}

Source: Field data (2017).

respects and takes the union and its activities seriously $2.4 \%$ of respondents strongly agree that the government respects and takes the union and its activities seriously.

This can be reflected from the government efforts to make the operation of the trade unions free in the country. The ratification of two ILO conventions adopted in 1948 and 1949 set out the essential elements of the freedom of association, the right to organize and the importance of collective bargaining. The government also enacted Employment and Labor Relations Act No 6 of 2004 [17] which provide the legislative framework regarding the formation, registration and general operations and management of trade unions. It also sets the road map for strike and lockout action, collective bargaining, and employment dispute resolution. The Act defines trade unions and also the tripartite consultative mechanism.

\subsection{The General Performance of the Union on Fulfilling Its Objective as a Worker's Representation}

Table 6 shows the respondent's perception on the overall performance of TTU. The results indicated that $21.1 \%$ of respondents stated that the performance was not good at all. $23.9 \%$ indicated that its performance was poor and $44.0 \%$ Perceived that its performance was fair and 11.0 indicated that its performance was good.

The question "Has belonging to the union benefited you in any way?" was posed to the respondents and 106 respondents said "yes" while 90 respondents said "no". 13 of the respondents did not give any response.

The above results as shown in Table 7 depict that the members of the union perceived that the performance of the union is fair and some of them have benefited from belonging in the union. This result reflects with the earlier study done by Ongori H and Meti-Lysson J, (2011) [19] in Botswana.

\section{Conclusion, Recommendations and Limitations of the Study}

\subsection{Conclusion}

Of utmost significance to the study was to evaluate the effectiveness of trade unionism in Tanzania as workers' representations based on the perceptions of their 
Table 6. The respondent's rate about the union performance in protecting its members against unfair workplace practices and treatment at the place of work.

\begin{tabular}{rccccc}
\hline Label this column & Frequency & Percent & Valid Percent & Cumulative Percent \\
\hline & Failure & 44 & 21.1 & 21.1 & 21.1 \\
\multirow{3}{*}{ Valid } & Poor & 50 & 23.9 & 23.9 & 45.0 \\
& Fair & 92 & 44.0 & 44.0 & 89.0 \\
& Good & 23 & 11.0 & 11.0 & 100.0 \\
& Total & 209 & 100.0 & 100.0 & \\
\hline
\end{tabular}

Source: Field data (2017).

Table 7. Does Union benefit you in any way?

\begin{tabular}{lccccc}
\hline & & Frequency & Percent & Valid Percent & Cumulative Percent \\
\hline \multirow{4}{*}{ Valid } & No & 90 & 43.1 & 45.9 & 45.9 \\
& Yes & 106 & 50.7 & 54.1 & 100.0 \\
\multirow{2}{*}{ Missing } & Total & 196 & 93.8 & 100.0 & \\
Total & 23 & 13 & 6.2 & & \\
\hline
\end{tabular}

Source: Field data, 2017.

members. Critical areas of measuring effectiveness of trade unions were examined such as union ability of sharing information with its members, responsiveness of trade unions towards members' problems and complains; the employer's attitude towards unions and the general performance of the trade unions as to fulfill its objectives as worker's representation.

In light of the above it can be concluded from this study that members of TTU have positive perception on the effective of TTU as a workers' representation and do represents its members. But there is a problem in areas of communication and keeping the members up to date on what is real going on within the union. This has been a major concern for members who think that they are being marginalized by the union executive and many think that executive do pursue their own interest at the expense of its members. This has in fact made them reluctant to show interest to union activities.

\subsection{Recommendations}

Based on the results from the study it can be recommended therefore that, the unions have to ensure that there is always an organic link between the unions and members at the grassroots. To this end, the participation of members in various trade union matters is of paramount importance. Union members should exactly know what is going on within the union.

Furthermore, unions need to expand their image and convince the workers that they can deliver the goods to the expectations of their members. 


\subsection{Limitations}

Although the findings of the study found to be reliable, the fact that a small sample size of the respondents (209) were involved and restricted to a single Trade union (TTU) the results limit the possibility of generalizing the findings to all trade unions in Tanzania. Future research on this subject could focus on extending the studies of this nature to a wide range of Trade Unions to include diverse respondents. However despite the aforementioned limitations the study findings offer a profound contribution to the ever expanding knowledge on Trade unionism in developing Africa.

\section{References}

[1] Schillinger, H.R. (2005) Trade Unions in Africa: Weak but Feared. Global Trade Union Programme; Friedrich-Ebert Stiftung.

[2] Babeiya, E. (2011) Trade Unions and Democratization in Tanzania: End of an Era? Journal of Politics and Law, 4. https://doi.org/10.5539/jpl.v4n1p123

[3] Thomas, H (1999) Trade Unions and Development; Discussion Papers: Institute of Social Studies, Geneva.

[4] Mukandala, S.R. (1999) Trade Un Ions in Tanzania: The Case of the Tanzania Federation of Trade Unions (TFTU) and Government. University of Dar es Salaam-Dar esSalaaam-Tanzania

[5] Kamugisha, J.D. Tefurukwa, W.O (2015) Trade Unions Panorama in Tanzania: Emerging Quandaries and the Way Forward. International Journal of Arts and Entrepreneurship, 4, 107-132.

[6] Bryson, A. (2003) Working with dinosaurs? Union Effectiveness in delivering for employees. Policy Studies Institute.

[7] Ghosh, P., Nandan, S. and Gupta, A. (2009) The Changing Roles of Trade Unions in India: A Case Study of National Thermal Power Corporation (NTPC). Unchahar. Asian Academy of Management Journal, 14.

[8] International Labour Organization (ILO) Caribbean (2013).

[9] Gibson, J.L (1991) Organizations: Behaviors, Structure and Process. McGraw-Hill, New York

[10] Zammuto, R.F. (1982) Assessing Organizational Effectiveness: Systems Change, Adaptation and Strategy. Suny Press.

[11] Cameron, K.S. (1986) A Study of Organizational Effectiveness and Its Predictors. Management Science, 32, 87-112. https://doi.org/10.1287/mnsc.32.1.87

[12] Shivji, I.G. (1986) Law, State and Working Class in Tanzania. Tanzania Publishing House, Dar es Salaam.

[13] Bana, B. (2011) Trade Unions Policy and Legal Changes in REDET. In: Trade Unionism in Tanzania: Policy, Participation and Autonomy, REDET, Dar es Salaam.

[14] URT (1998) Trade Unions Act No. 10

[15] Bana, B. and Mukandala, R. (2006) The Search for Independent Organization: The long Road to the TUCTA. In: Kiondo, A.S. and Nyang'oro, J.E., Eds., Civil Society and Democratic Development in Africa. Harare, Zimbabwe.

[16] URT (1998) Trade Unions Act No. 10.

[17] URT (2004) Employment and Labour Relations Act No. 6. 
[18] Mpangala, G. (2006) Civil Society. A Paper presented at the Conference on the State of Politics in Tanzania held at the University of Dar es Salaam. University of Dar es Salaam, Dar es Salaam.

[19] Moeti-Lysson \& Ongori H (2011) Effectiveness of Trade Unions in Promoting Employee Relations in Organizations. Global Journal of Arts and Management, 1. 